\title{
TOLERANCE LEVEL OF GREEN SEED IN SOYBEAN SEED LOTS AFTER STORAGE ${ }^{1}$
}

\author{
GILDA PIZZOLANTE DE PÁDUA² ${ }^{2}$ JOSÉ DE BARROS FRANÇA-NETO³ ${ }^{3}$, MARIA LAENE MOREIRA DE CARVALHO ${ }^{4}$, \\ ODAIR COSTA ${ }^{5}$, FRANCISCO CARLOS KRZYZANOWSKI ${ }^{6}$, NILTON PEREIRA DA COSTA ${ }^{7}$
}

\author{
NÍVEL DE TOLERÂNCIA DE SEMENTES ESVERDEADAS EM LOTES \\ DE SEMENTES DE SOJA APÓS ARMAZENAMENTO
}

\begin{abstract}
RESUMO - Ocorrência de sementes de soja esverdeadas, devido à maturação forçada de plantas ou sua morte prematura, causada por seca ou por doenças de raiz ou foliares, tem sido freqüente em diversas regiões brasileiras. A qualidade fisiológica de lotes com sementes esverdeadas pode ser afetada tanto em relação ao seu potencial de germinação quanto ao seu vigor, a ponto de inviabilizar sua comercialização. A determinação desse ponto que estabelece o nível máximo tolerado de sementes esverdeadas nos lotes é informação de extrema importância para os produtores de sementes. O objetivo do experimento foi determinar o nível tolerado de sementes esverdeadas em lotes de sementes de soja, que não comprometa a sua qualidade para fins comerciais. Foram utilizadas sementes de soja das cultivares CD 206, produzidas em Ubiratã, PR e de 'FMT Tucunaré', produzidas em Alto Garças, MT. Sementes esverdeadas foram mescladas com sementes amarelas nos seguintes porcentuais: $0 \%, 3 \%, 6 \%, 9 \%, 12 \%, 15 \%, 20 \%, 30 \%, 40 \%, 50 \%, 75 \%$ e $100 \%$. A qualidade das sementes foi avaliada pelos testes de germinação, envelhecimento acelerado, tetrazólio e condutividade elétrica. Foram também determinados os teores de clorofila $a, b$ e total nas sementes. O delineamento experimental utilizado foi blocos casualizados com três repetições, em esquema fatorial (duas cultivares x 12 níveis de sementes esverdeadas). A qualidade das sementes foi afetada negativamente e os teores de clorofilas se elevaram com o aumento dos porcentuais de sementes esverdeadas. Índices de até 3\% de sementes esverdeadas, em lotes de sementes de soja, não propiciaram reduções na germinação, na viabilidade e no vigor, pelo envelhecimento acelerado, nas duas cultivares em estudo. A partir de $6 \%$ de sementes esverdeadas, a sua qualidade apresenta reduções significativas. Níveis superiores a 9\% de sementes esverdeadas comprometem a qualidade de lotes de sementes de soja para fins comerciais, por seus efeitos significativos na redução do potencial fisiológico.
\end{abstract}

Termos para indexação: Glycine max, clorofila, deterioração, vigor.

\section{TOLERANCELEVEL OF GREEN SEED IN SOYBEAN SEEDLOTS AFTER STORAGE}

\begin{abstract}
The occurrence of green soybean seed due to forced maturation or premature plant death caused by drought or foliar and/or root diseases has been common in several Brazilian production areas. Physiological quality of seed lots with green seed may have their germination and vigor potentials affected and therefore discarded by the grain industry. The objective of this experiment was to determine the maximum tolerated level of green seed in soybean seed lots, which is information of major importance for seed producers when taking the decision whether to sell these lots. Soybean seed of the cultivars CD 206, produced in Ubirata, Parana, and 'FMT Tucunare,' produced in Alto Garças, Mato Grosso, were used in the study. Green seed and yellow seed of both cultivars were mixed in the following proportions: $0 \%, 3 \%, 6 \%, 9 \%, 12 \%, 15 \%, 20 \%, 30 \%, 40 \%, 50 \%, 75 \%$ and $100 \%$. Seed quality was evaluated by the germination, accelerated aging, tetrazolium and electrical conductivity tests. The contents of $a, b$ and total chlorophyll
\end{abstract}

\footnotetext{
${ }^{1}$ Submetido em: 12/09/2006 Aceito para publicação em: 20/06/2007. Parte da Tese de Doutorado do primeiro autor apresentada a UFLA.

${ }^{2}$ Eng $^{\circ}$ Agr $^{\circ}$, pós graduanda do Departamento de Agricultura, UFLA. Pesq. Embrapa/EPAMIG. E-mail: gpadua@ufla.br

${ }^{3}$ Eng $^{\circ}$ Agr $^{\circ}$, Ph.D., Pesquisador Embrapa Soja. E-mail: jbfranca@ @npso.embrapa.br

${ }^{4} \mathrm{Eng}^{\mathrm{c}} \mathrm{Agr}^{\mathrm{o}}$, Ph.D., Prof. Adjunto, Depto Agricultura, UFLA. E-mail: mlaenemc@ufla.br

${ }^{5}$ Eng $^{\mathrm{c}} \mathrm{Agr}^{\mathrm{o}}$, Responsável Técnico Sementes Adriana. E-mail: odair@ sementesadriana.com.br

${ }^{6}$ Eng $^{\circ}$ Agr $^{\circ}$, Ph.D., Pesquisador Embrapa Soja. E-mail: fck@ cnpso.embrapa.br

${ }^{7}$ Eng $^{\circ}$ Agr ${ }^{\circ}$, Ph.D., Pesquisador Embrapa Soja. E-mail: nilton@ @npso.embrapa.br
} 
in the seed were also determined. A complete randomized block design in a factorial scheme (two cultivars $\mathrm{x} 12$ levels of green seed) was used. Seed quality was negatively affected and chlorophyll contents incremented with the increase in the percentage of green seed. Seed germination, viability and vigor, measured by the accelerated aging test, were not reduced with levels of up to 3\% green seed, for both cultivars. Levels above 6\% green seed significantly reduced the quality of the seed. The quality of seed lots with $9 \%$ or more green seed was significantly reduced to the point that their commercialization is not recommended.

Index terms: Glycine max, chlorophyll, deterioration, vigor.

\section{INTRODUCTION}

The incidence of green seed in soybean seed lots is a problem that occurs in tropical countries, such as Brazil, where climatic conditions are characterized by high temperatures and great variations in rainfall, mainly in the final seed maturation period.

Green seed occurrence is the result of unfavorable climatic conditions (extremely hot and dry, in the last seed maturation stages) or of premature harvesting techniques that interfere in the chlorophyll degradation process that makes the green coloring disappear. It is believed that with premature plant death and the consequent forced seed maturation, the chlorophyllase enzyme activity stops before all the chlorophyll is degraded (Bohner, 2005).

In spite of the importance of chlorophyll transformation into its derivatives during soybean maturing, little is known about the pigment degradation mechanism in this seed (Ward et al., 1995) during the maturing and storing process. These levels of pigmentation can be strongly affected either by the development stage or by the climatic conditions that can interfere in the seed maturation process (Sinnecker, 2002).

Chlorophyll degradation starts at senescence, because of endogenous factors and can also be influenced by external factors, such as water shortage, light reduction, temperature changes, increase in ethylene content or by internal factors, such as increase in membrane permeability and change in $\mathrm{pH}$. These factors interfere in the normal process, leading to acceleration or delay in chlorophyll degradation (Heaton and Marangoni, 1996; Takamiya et al., 2000).

The occurrence of seeds with intense dark green coloring, especially involving the embryonic axis area (green seed) was reported by Costa et al. (2001) with great frequency in Brazilian producing regions in recent growing seasons. Soybean seed with these characteristics generally presents high indices of deterioration caused by weathering, that can lead to reduced germination and vigor that reflects in the commercialization of these seed lots. These reflexes are not always observed when sowing is carried out immediately after harvest, but after storage in uncontrolled conditions, the effect of the incidence of green seed incidence is aggravated. Thus the presence of green seed results in low commercial value and losses when the objective is commercialization.

Determining of the point that establishes the maximum tolerated level of green seed in seed lots is extremely important information for soybean seed producers, because it helps in decision taking on the harvest, processing and commercialization.

Thus the objective of this research was to determine the tolerated level of green seed in soybean seed lots that does not damage its quality for commercial purposes.

\section{MATERIAL AND METHODS}

Seeds were used of the soybean cultivars CD 206, produced in Ubiratã, PR and FMT Tucunaré, produced in Alto Garças, MT. The seeds were stored in chambers at $20^{\circ} \mathrm{C}$ and $60 \%$ RH for five months, from May to September 2005 , before the assessments. The physiological quality analyses were carried out in the Seed Analysis Laboratory at Embrapa Soybean, and the electric conductivity test and the chlorophyll content determination were performed in the laboratory at the Department of Agriculture at the Federal University of Lavras, MG.

The occurrence of green seed in the CD 206 cultivar was the consequence of water shortage during the final seed maturing stage. These seeds occurred in the FMT Tucunare cultivar because of excessive rainfall that resulted in the occurrence of fusariosis in the plant roots, causing an early death and consequently forced maturation. It was further observed that the green seeds in the CD 206 cultivar 
presented a more intense green coloring compared to those of FMT Tucunaré.

To obtain the treatments, the green seed was separated and then mixed with yellow seed from the same lots from the CD 206 and FMT Tucunare cultivars, in the following percentages: $0 \%, 3 \%, 6 \%, 9 \%, 12 \%, 15 \%, 20 \%, 30 \%, 40 \%$, $50 \%, 75 \%$ and $100 \%$. The seeds were assessed by the germination, accelerated aging, tetrazolium and electric conductivity tests. The $a, b$ and total chlorophyll contents were determined in the seed.

Germination test: carried out with four sub-samples of 50 seeds per experimental unit, sown in rolled paper substrate, moistened with a quantity of water equivalent to 2.5 times the paper dry weight. The rolls were kept in a germinator previously regulated at constant $25^{\circ} \mathrm{C}$. Assessments were made at five and eight days after setting up the tests, following the criteria established by the Rules for Seed Analysis (Brasil, 1992) and the results were expressed in percentage.

Accelerated aging test: four sub-samples of 50 seeds were used per experimental unit, placed in a single layer on aluminum wire mesh tray, in plastic boxes containing $40 \mathrm{ml}$ distilled water at the bottom. The plastic boxes were closed and kept in a water jacket incubator adjusted to $41^{\circ} \mathrm{C}$ for 48 hours (Marcos Filho, 1999). After the aging period, the seed were submitted to the germination tests, according to the Rules for Seed Analysis (Brasil, 1992), and a single assessment was made at five days when the percentage of normal seedlings was calculated.

Tetrazolium test: two sub-samples of 50 seeds per experimental unit were placed in wet paper towel substrate, with a quantity of water equivalent to 2.5 times the paper dry weight, for 16 hours at $25^{\circ} \mathrm{C}$ in a temperature controlled chamber. Later the seeds were placed in solution with $0.075 \%$ concentration of 2, 3, 5-tryphenyl tetrazolium chloride, in the dark in a chamber at $40^{\circ} \mathrm{C}$ for 2.5 hours. After this period, the seeds were washed in running water and analyzed individually. The vigor, viability and damage percentages were ascertained according to methodology reported by França-Neto et al. (1998).

Electric conductivity test: carried out with four subsamples of 50 seeds of the pure seed fraction, weighed with $0.01 \mathrm{~g}$ precision, placed in plastic cups containing 75 $\mathrm{ml}$ deionized water and kept in an incubator at constant $25^{\circ} \mathrm{C} \pm 1^{\circ} \mathrm{C}$, for 24 hours. In the same environment a cup was left containing only $75 \mathrm{ml}$ deionized water (Vieira \& Krzyzanowski, 1999). After this phase, the electric conductivity was read of the solutions, using a Digimed conductivity meter model CD 21A. The results were obtained by calculating the observed electric conductivity for each replication, divided by the seed weight, expressed in $\mu \mathrm{S} . \mathrm{cm}^{-1} \cdot \mathrm{g}^{-1}$.

Chlorophyll contents determination: the method by Arnon (1994) was used to carry out these analyses, adapted as next described. Twenty seeds from each sub-sample per treatment were ground using liquid nitrogen plus one aliquot of polyvinyl pyrrolidone (PVP), weighed and packed in a black plastic recipients and kept in a deep freezer at $86^{\circ} \mathrm{C}$ until handling. To extract the chlorophyll, $3.0 \mathrm{~g}$ of ground seeds were used, which were resuspended with 5 $\mathrm{mL} 80 \%$ acetone in a dark room using green light. The extract was filtered through fiberglass and placed in an amber flask; the resuspended residue was washed until it completed $15 \mathrm{ml}$ extract, kept in an ice bath until absorbency reading in an electrophotometer at $645 \mathrm{~nm}$ and $663 \mathrm{~nm}$ wavelengths. The chlorophyll contents were calculated in $\mathrm{mg} \cdot \mathrm{g}^{-1}$ according to the equations:

Chlorophyll $a\left(\mathrm{mg} \cdot \mathrm{g}^{-1}\right)=\left[\left(12.7 \cdot \mathrm{A}_{663}\right)-\left(2.69 \cdot \mathrm{A}_{645}\right)\right] \times \mathrm{FC}$ Chlorophyll $b\left(\mathrm{mg} \cdot \mathrm{g}^{-1}\right)=\left[\left(22.9 . \mathrm{A}_{645}\right)-\left(4.68 . \mathrm{A}_{663}\right)\right] \times \mathrm{FC}$ Chlorophyll total $\left(\mathrm{mg} \cdot \mathrm{g}^{-1}\right)=\left[\left(20 \cdot 2 \cdot \mathrm{A}_{645}\right)+\left(8.02 \cdot \mathrm{A}_{663}\right)\right] \times \mathrm{FC}$ where: $\mathrm{A}=$ absorbency at the underwritten wavelength;

$$
\mathrm{FC}=\text { correction factor }=15 \mathrm{~mL} / 3 \mathrm{~g}=5
$$

Statistical analysis: a randomized block design was used with three replications in a 12 x 2 factorial scheme ( 12 green seed levels and two cultivars), for all the variables analyzed.

The data were interpreted statistically by analysis of variance. Angular logarithmic transformations were needed for some variables. The means were compared by the Scott Knott test at $5 \%$ probability.

Regression analyses were made for each cultivar, assessing the effects of the percentages of green seed on the quality parameters studied. The statistical softwares $\mathrm{R}^{\circledR} \mathrm{v} 2.1 .1(\mathrm{R}, 2005)$ and SISVAR $^{\circledR} \mathrm{v} 4.3$ were used (Ferreira, 2000) for all the statistical analyses carried out in this study. 


\section{RESULTS AND DISCUSSION}

Analysis of variance of the data

In the interaction among the factors, green seed percentage and cultivars, there were significant differences for the germination, accelerated aging, tetrazolium (viability and weathering damage) and $a$ chlorophyll content tests. The interaction between the two factors was not significant for the electric conductivity, tetrazolium (vigor and mechanical damage) and the $b$ and total chlorophyll contents tests.

\section{Germination, tetrazolium and accelerated aging tests}

Figure 1 shows significant linear order effects for germination in the two cultivars analyzed in function of the green seed percentage. It was observed that germination decreased gradually as the green seed incidence increased. Analysis of variance showed that indices of up to $3 \%$ green seed, in a soybean seed lot, did not differ from the control and did not present reductions in germination, viability by tetrazolium (1-5) and vigor by the accelerated aging tests, in the two cultivars studied (Table 1). Germination values were observed for the CD 206 and FMT Tucunare of 81\% and $86 \%$, respectively, with $9 \%$ green seed incidence. Beyond this level, that is, levels higher than $9 \%$ green seed in seed lots, the quality of the lot may be harmed for commercial purposes because of the significant effects of the reduction in seed germination, vigor and viability.

For all the parameters assessed, the seed quality of the CD 206 cultivar was always lower than that of FMT Tucunaré. In a similar study carried out by Medina et al. (1997) it was detected that the incidence of $20 \%$ green seed, found in soybean seed lots in the IAC-15, IAC-17, IAC-Foscarin-31 and FT Cometa cultivars, significantly affected germination of the seed of these cultivars.

Costa et al. (2001) worked with four levels of green seed in soybean, and emphasized that at the $80 \%$ germination minimum commercial standard of certified seeds, the occurrence of more than $10 \%$ green seed found in seed lots severely damaged germination, so that lots were discarded, they could not be sold and there were serious losses for the soybean seed producers.

Figures 2 (a) and 2 (b) show that viability and vigor by tetrazolium fitted the linear models. The greatest viability values (Figure 2 and Table 1) were obtained in the seeds that presented levels of up to $9 \%$ green seed. At this level, values of $81 \%$ and $83 \%$ viability were observed in the CD 206 and FMT Tucunaré cultivars, respectively. It was detected that indices greater than $9 \%$ seeds with green pigment present led to sharp decreases in viability, indicating that the seeds, on the whole, were either dead or produced abnormal seedlings. Vigor, detected by the tetrazolium test (Figure 2b) was negatively affected with the increase in the percentage of green seed, presenting maximum vigor $(82 \%)$ in the control and reduction to $68 \%$ for the $9 \%$ green seed level (Table 2). The study reported by Costa et al. (2001) showed that, starting at levels of $10 \%$ green seed found in soybean seed lot, there may occur reduction in vigor, viability and germination. The authors further emphasized that the greening concentration in areas close to the radicle, plumule and hypocotyls caused more drastic damage to the seeds, resulting in high deterioration and low vigor indexes.

The results of the index of deterioration caused by weathering (level 6-8), detected by the tetrazolium test (Figure 2c), fitted the linear models for the two cultivars. There was no deterioration caused by weathering in seeds of the control and those with $3 \%$ green seed, in either cultivar (Table 1). A serious problem was detected of deterioration by weathering (TZ 6-8) starting from the occurrence of $6 \%$ green seed; this problem became more serious with the incidence of indexes greater than $9 \%$ seeds with the presence of the green pigment, in the lots of the two cultivars under study.

These results are in line with those observed by Costa et al. (2001) who used four soybean cultivars and four green seed levels. The authors observed that percentages of green seed greater than $10 \%$ generally led to problems in the physiological quality. They also verified that green seed incidence was directly related to the indexes of deterioration by weathering and that as the green seed level increased in lots with high physiological standard, a sharp reduction was usually observed in seed germination, vigor and viability. Similar results were reported by Medina et al. (1997) and Pupim et al. (2005) who detected that the presence of green seed expressively affected the soybean seed quality. Zorato 


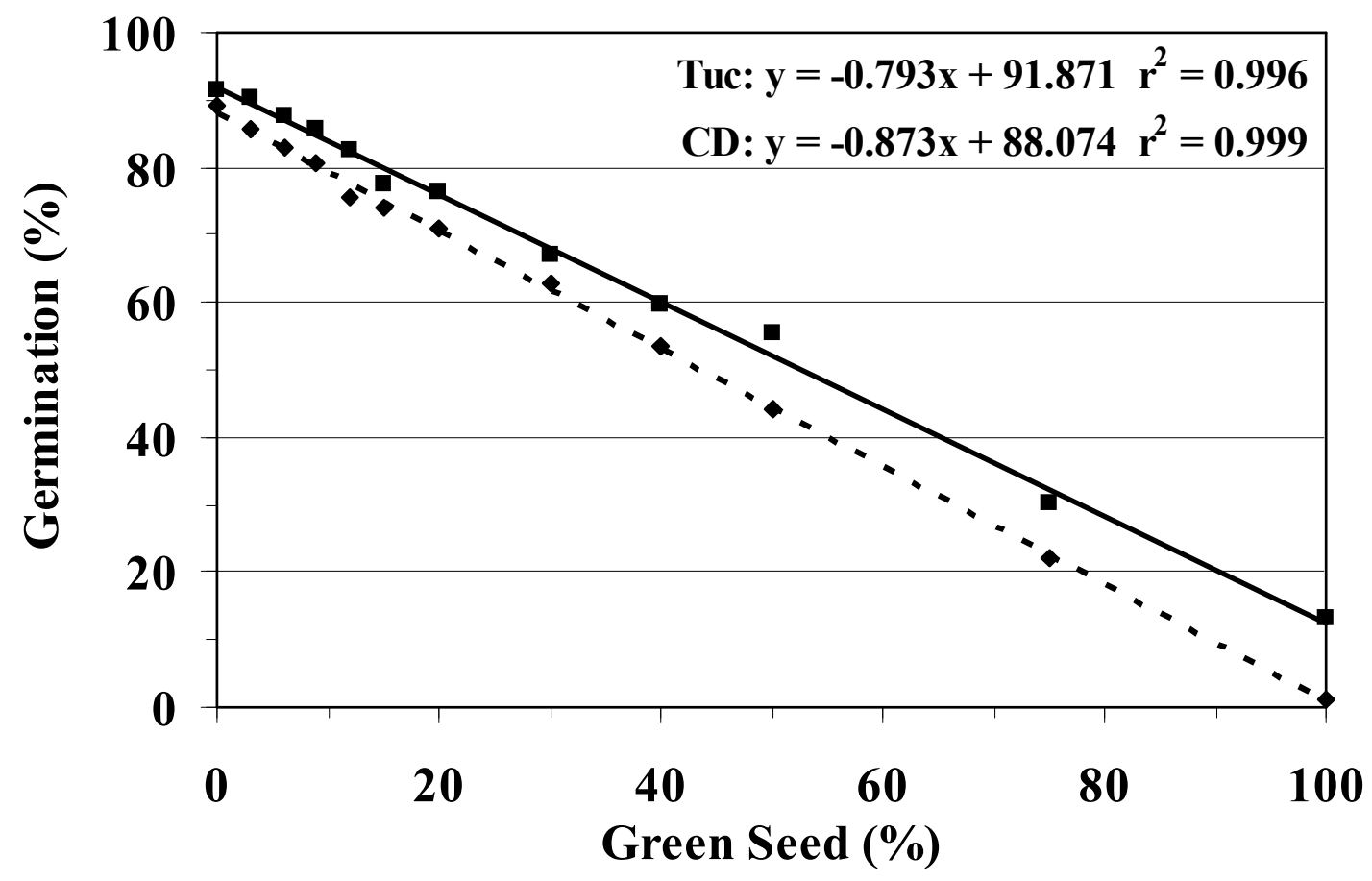

FIGURE 1 - Soybean seed germination of the CD 206 (CD) and FMT Tucunaré (Tuc) cultivars in function of green seed percentage. UFLA, Lavras, MG, 2006.

TABLE 1 - Effect of green seed levels on germination, vigor (accelerated aging), viability and deterioration index by weathering detected by the tetrazolium tests, in soybean seeds of the CD 206 (CD) and FMT Tucunaré (Tuc) cultivars. UFLA, Lavras, MG, 2006.

\begin{tabular}{|c|c|c|c|c|c|c|c|c|}
\hline \multirow[t]{2}{*}{$\begin{array}{c}\text { Green } \\
\text { Seed } \\
(\%)\end{array}$} & \multicolumn{2}{|c|}{$\begin{array}{c}\text { Germination } \\
(\%)\end{array}$} & \multicolumn{2}{|c|}{$\begin{array}{l}\text { Acc. } \\
\text { Aging } \\
(\%)\end{array}$} & \multicolumn{2}{|c|}{$\begin{array}{c}\text { TZ (1-5) Viability } \\
(\%)\end{array}$} & \multicolumn{2}{|c|}{$\begin{array}{c}\text { TZ (6-8) } \\
\text { Weathering Damage } \\
(\%)\end{array}$} \\
\hline & CD & Tuc & CD & Tuc & CD & Tuc & CD & Tuc \\
\hline$\overline{\mathbf{0}}$ & $89 \mathrm{aA}$ & $91 \mathrm{aA}$ & $85 \mathrm{aA}$ & $84 \mathrm{aA}$ & $89 \mathrm{aA}$ & $92 \mathrm{aA}$ & $0 \mathrm{aA}$ & $6 \mathrm{aB}$ \\
\hline 3 & $86 \mathrm{aB}$ & $90 \mathrm{aA}$ & $82 \mathrm{aA}$ & $82 \mathrm{aA}$ & $86 \mathrm{aA}$ & $89 \mathrm{aA}$ & $3 \mathrm{aA}$ & $9 \mathrm{aB}$ \\
\hline 6 & $83 \mathrm{bB}$ & $88 \mathrm{bA}$ & $79 \mathrm{bA}$ & $81 \mathrm{aA}$ & $84 \mathrm{bB}$ & $88 \mathrm{aA}$ & $8 \mathrm{bA}$ & $10 \mathrm{aA}$ \\
\hline 9 & $81 \mathrm{bB}$ & $86 \mathrm{bA}$ & $76 \mathrm{cA}$ & $77 \mathrm{bA}$ & $81 \mathrm{cA}$ & $83 \mathrm{bA}$ & $11 \mathrm{cA}$ & $15 \mathrm{bA}$ \\
\hline 12 & $74 \mathrm{cB}$ & $83 \mathrm{cA}$ & $73 \mathrm{cA}$ & $75 \mathrm{bA}$ & $76 \mathrm{~dB}$ & $82 \mathrm{bA}$ & $13 \mathrm{cA}$ & $16 \mathrm{bA}$ \\
\hline 15 & $76 \mathrm{cA}$ & $78 \mathrm{dA}$ & $68 \mathrm{dA}$ & $70 \mathrm{cA}$ & $70 \mathrm{~dB}$ & $80 \mathrm{bA}$ & $19 \mathrm{dA}$ & $19 \mathrm{cA}$ \\
\hline 20 & $71 \mathrm{cB}$ & $76 \mathrm{dA}$ & $65 \mathrm{eA}$ & $65 \mathrm{dA}$ & $70 \mathrm{eB}$ & $75 \mathrm{cA}$ & $21 \mathrm{dA}$ & $23 \mathrm{cA}$ \\
\hline 30 & $63 \mathrm{dA}$ & $67 \mathrm{eA}$ & $55 \mathrm{fB}$ & $63 \mathrm{dA}$ & $63 \mathrm{eA}$ & $65 \mathrm{dA}$ & $33 \mathrm{eA}$ & $34 \mathrm{dA}$ \\
\hline 40 & $53 \mathrm{eB}$ & $60 \mathrm{fA}$ & $45 \mathrm{gB}$ & $55 \mathrm{eA}$ & $54 \mathrm{fB}$ & $63 \mathrm{dA}$ & $41 \mathrm{fA}$ & $37 \mathrm{dA}$ \\
\hline 50 & $44 \mathrm{fB}$ & $56 \mathrm{fA}$ & $33 \mathrm{hB}$ & $46 \mathrm{fA}$ & $47 \mathrm{gB}$ & $53 \mathrm{eA}$ & $51 \mathrm{gB}$ & $46 \mathrm{eA}$ \\
\hline 75 & $22 \mathrm{gB}$ & $30 \mathrm{gA}$ & $17 \mathrm{iB}$ & $33 \mathrm{gA}$ & $27 \mathrm{hB}$ & $32 \mathrm{fA}$ & $71 \mathrm{hA}$ & $68 \mathrm{fA}$ \\
\hline 100 & $1 \mathrm{hB}$ & $13 \mathrm{hA}$ & $0 \mathrm{jB}$ & $12 \mathrm{hA}$ & $5 \mathrm{iB}$ & $20 \mathrm{gA}$ & $94 \mathrm{iB}$ & $80 \mathrm{gA}$ \\
\hline $\mathrm{CV}(\%)$ & \multicolumn{2}{|c|}{3.95} & \multicolumn{2}{|c|}{3.31} & \multicolumn{2}{|c|}{3.91} & \multicolumn{2}{|c|}{8.39} \\
\hline
\end{tabular}

Means followed by the same uppercase letter on the line and lowercase letter in the column do not differ by the Scott-Knott test at $5 \%$ probability. 
et al. (2003) studied the MG/BR 46 (Conquista) cultivar with $11.8 \%$ and $37.4 \%$ green seed and reported less germination, less vigor (accelerated aging and electric conductivity), greater deterioration rates (tetrazolium) and smaller weight of 1000 seed with increase in green seed percentage.

Mechanical damage, detected by the tetrazolium test (Table 2), did not affect the seed performance at any of the percentage levels of green seed. A similar result was observed by Costa et al. (2001) indicating that the occurrence of green seed in seed lots might be associated to adverse climate conditions at the end of the seed maturing process.

Seed quality, assessed by the accelerated aging test (Figure 3), decreased with the increase in the green seed indices. The maximum values estimated for CD 206 (85\%) and for FMT Tucunaré (84\%) were obtained in the control and decreased to $76 \%$ and $77 \%$, respectively, when the seeds presented $9 \%$ seed with chlorophyll retention found, and starting at $15 \%$ incidence, the reductions were more drastic (Table 1).

\section{Electric conductivity test}

The results obtained in the electric conductivity test (Figure 4) fitted the linear models. It was evident from the test that green seeds, because they presents greater indexes of solute lixiviation, had disorganized cell membrane systems, consequence of forced maturing and premature plant death. The destructuring and loss of the integrity of the cell membrane system caused alterations in the metabolism and electrolyte exudates between the cells and the external media, with direct reflexes on the seed physiological quality. According to França-Neto et al. (2005) adverse climatic conditions, such as intense drought during the maturing phases of the soybean crop, result in forced maturing of the seeds that in turn result in low yields and green seed occurrence that would result in a sharp reduction in their quality, in addition to severe reduction in the crop productivity.

The electric conductivity in the control seeds was 81 $\mu \mathrm{S} . \mathrm{cm}^{-1} \cdot \mathrm{g}^{-1}$, while at the levels of $3 \%, 6 \%$ and $9 \%$ green seed, the conductivity values were 87,100 and $104 \mu$ S.cm ${ }^{1} . \mathrm{g}^{-1}$, respectively (Table 2 ).
Paiva Aguero (1995) reported for soybean seed that under small limitations for germination, conductivity could not be greater than $90 \mu \mathrm{S} \cdot \mathrm{cm}^{-1} \cdot \mathrm{g}^{-1}$. On the other hand, Vieira (1994) reported that the standards to be considered for soybean seed lots with high vigor should be conductivity up to $70-80 \mu \mathrm{S} \cdot \mathrm{cm}^{-1} \cdot \mathrm{g}^{-1}$, although the author stated that they are values with strong tendency to present medium vigor.

Thus, lots with green seed incidence greater than $6 \%$ present more accentuated deterioration and consequently reductions in seed germination, viability and vigor. Mills et al. (1999) observed in lentils that changes in the $\mathrm{pH}$, electric conductivity and germination were related to alterations in seed color and could be used as a method to assess their quality.

\section{$a, b$ and total chlorophyll contents}

The responses to the green seed percentage on the $a, b$ and total chlorophyll contents fitted the linear models, for the CD 206 and FMT Tucunaré cultivars (Figure 5).

The $a$ and total chlorophyll contents increased with the rise in the percentage of seeds with green pigment, presenting higher values above $9 \%$ occurrence of these seeds (Table 3 ).

Lower values of $b$ chlorophyll, shown in Figure 5 (b), were observed compared to $a$ chlorophyll (Table 3 ). Similarly, the $b$ chlorophyll contents increased as the percentage of green seed increased. In the absence of these seeds (control) and at the $3 \%$ green seed incidence, there was no significant difference for the $b$ chlorophyll contents.

The presence of seeds with chlorophyll retention is the result of unfavorable climatic conditions, mainly an extremely hot and dry climate, during the last maturing stages of the seeds, when the degradation process of this pigment, that causes the green color to disappear, is influenced. It is believed that with premature plant death and the consequent forced maturation of the seed, chlorophyllase enzyme activity stops before all the chlorophyll has been degraded (Bohner, 2005). The chlorophyll levels present in the seed are affected equally by the genotype and climatic conditions, especially temperature, in the seed maturing process (McGregor, 1991).

According to Schwartz and Lorenzo (1990), the $a: b$ chlorophyll ratio normally found in nature is approximately 3:1 in green leaves. In rapeseed, Johnson-Flanagan and 


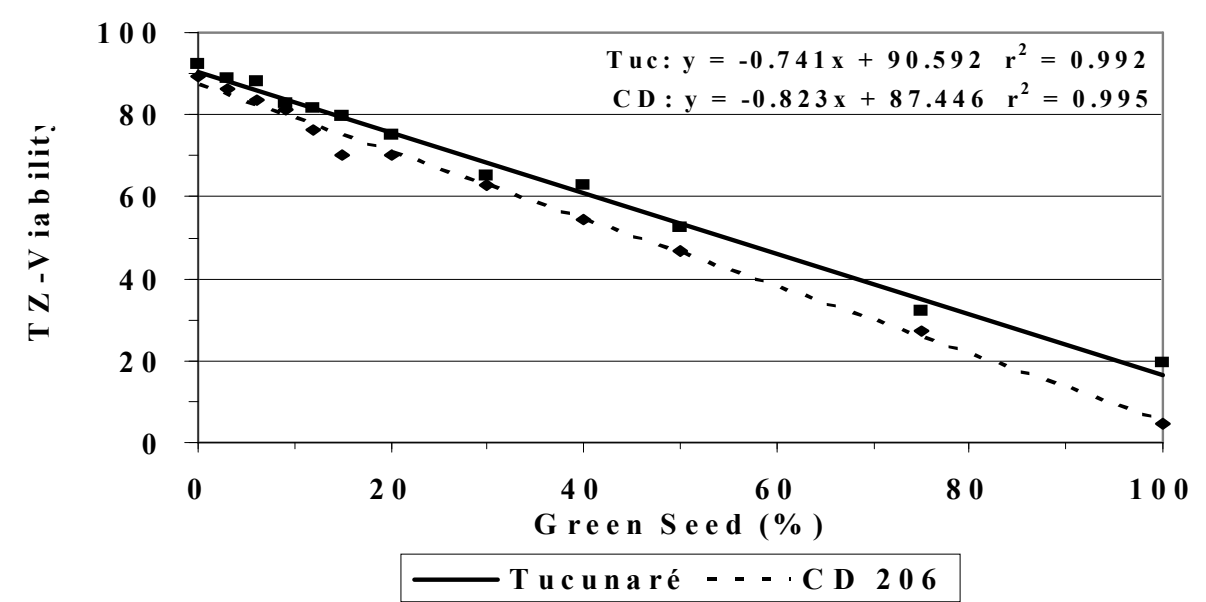

(a)

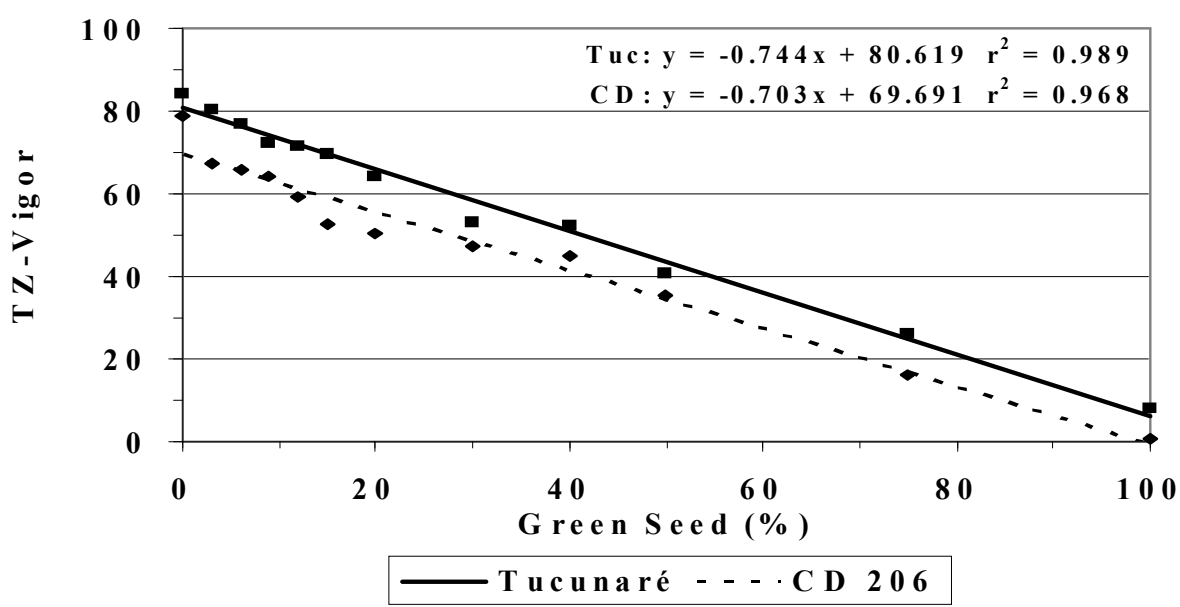

(b)

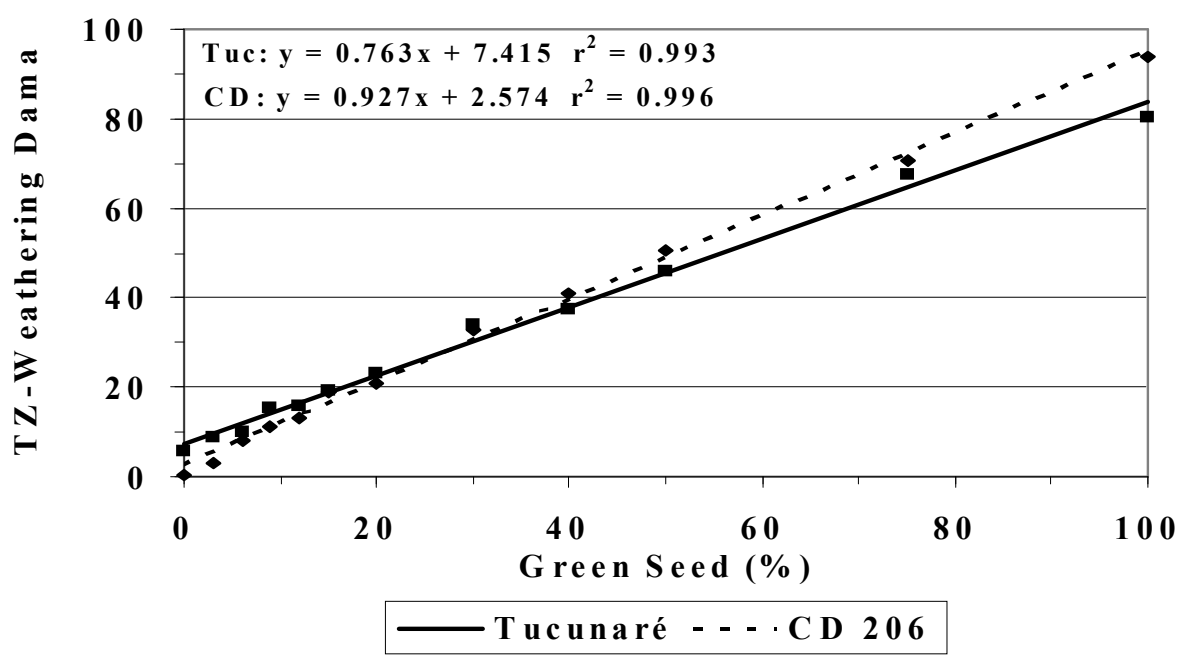

(c)

FIGURE 2 - Viability (a), vigor (b) and weathering damage, 6-8 level (c) determined by the tetrazolium tests in soybean seed of the CD 206 (CD) and FMT Tucunaré (Tuc) cultivars in function of the percentage of green seed. UFLA, Lavras, MG, 2006. 


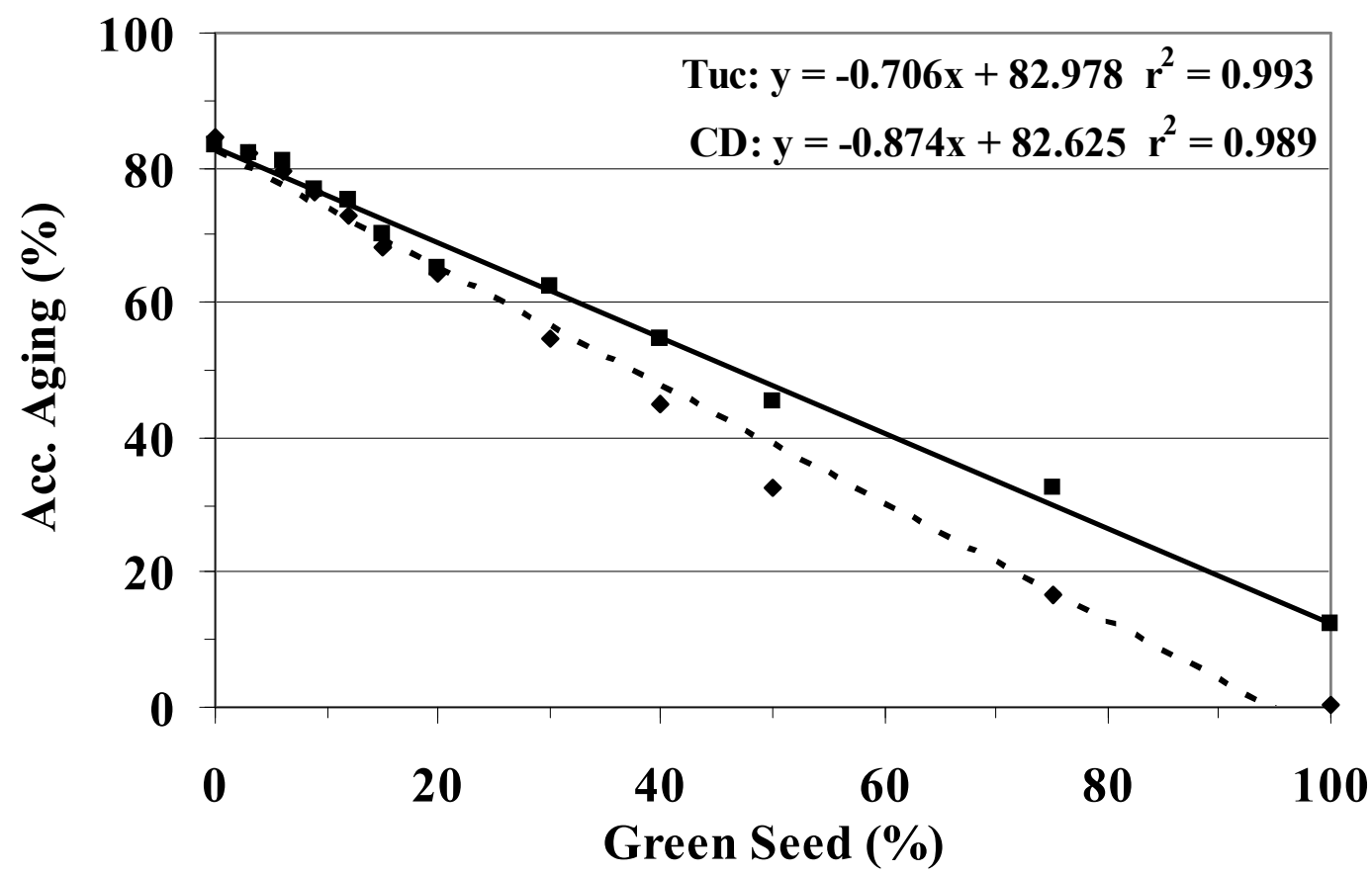

\section{Tucunaré - - . CD 206}

FIGURE 3 - Soybean seed germination of the CD 206 (CD) and FMT Tucunaré (Tuc) cultivars submitted to the accelerated aging test, in function of green seed percentage. UFLA, Lavras, MG, 2006.

TABLE 2 - Effect of green seed levels on vigor and on mechanical damage index detected by the tetrazolium test, and on electric conductivity in soybean seeds of the CD 206 and FMT Tucunaré cultivars. UFLA, Lavras, MG, 2006.

\begin{tabular}{|c|c|c|c|}
\hline $\begin{array}{c}\text { Green Seed } \\
(\%)\end{array}$ & $\underset{(\%)}{\text { Tetrazolium }}-$ Vigor & $\begin{array}{c}\text { Tetrazolium - } \\
\text { Mechanical Damage } \\
(\%)\end{array}$ & $\begin{array}{c}\text { Electric Conductivity } \\
\left(\mu \mathrm{S} . \mathrm{cm}^{-1} \cdot \mathrm{g}^{-1}\right)\end{array}$ \\
\hline 0 & $82 a$ & $5.7 \mathrm{a}$ & $81.3 \mathrm{a}$ \\
\hline 3 & $74 \mathrm{~b}$ & $5.8 \mathrm{a}$ & $87.0 \mathrm{~b}$ \\
\hline 6 & $71 \mathrm{~b}$ & $5.7 \mathrm{a}$ & $99.8 \mathrm{c}$ \\
\hline 9 & $68 c$ & $5.2 \mathrm{a}$ & $104.3 \mathrm{~d}$ \\
\hline 12 & $66 c$ & $6.7 \mathrm{a}$ & $110.5 \mathrm{e}$ \\
\hline 15 & $60 d$ & $6.8 \mathrm{a}$ & $118.5 \mathrm{f}$ \\
\hline 20 & $59 \mathrm{~d}$ & $6.0 \mathrm{a}$ & $127.7 \mathrm{~g}$ \\
\hline 30 & $50 \mathrm{e}$ & $4.7 \mathrm{a}$ & $143.5 \mathrm{~g}$ \\
\hline 40 & $49 \mathrm{e}$ & $4.5 \mathrm{a}$ & $164.7 \mathrm{~h}$ \\
\hline 50 & $38 \mathrm{f}$ & $5.2 \mathrm{a}$ & $188.8 \mathrm{~h}$ \\
\hline 75 & $21 \mathrm{~g}$ & $4.5 \mathrm{a}$ & $233.0 \mathrm{i}$ \\
\hline 100 & $4 \mathrm{~h}$ & $5.7 \mathrm{a}$ & $291.8 \mathrm{j}$ \\
\hline C.V. (\%) & 6.99 & 29.54 & 1.22 \\
\hline
\end{tabular}

Means followed by the same uppercase letter on the line and lowercase letter in the column do not differ by the Scott-Knott tests at $5 \%$ probability. 


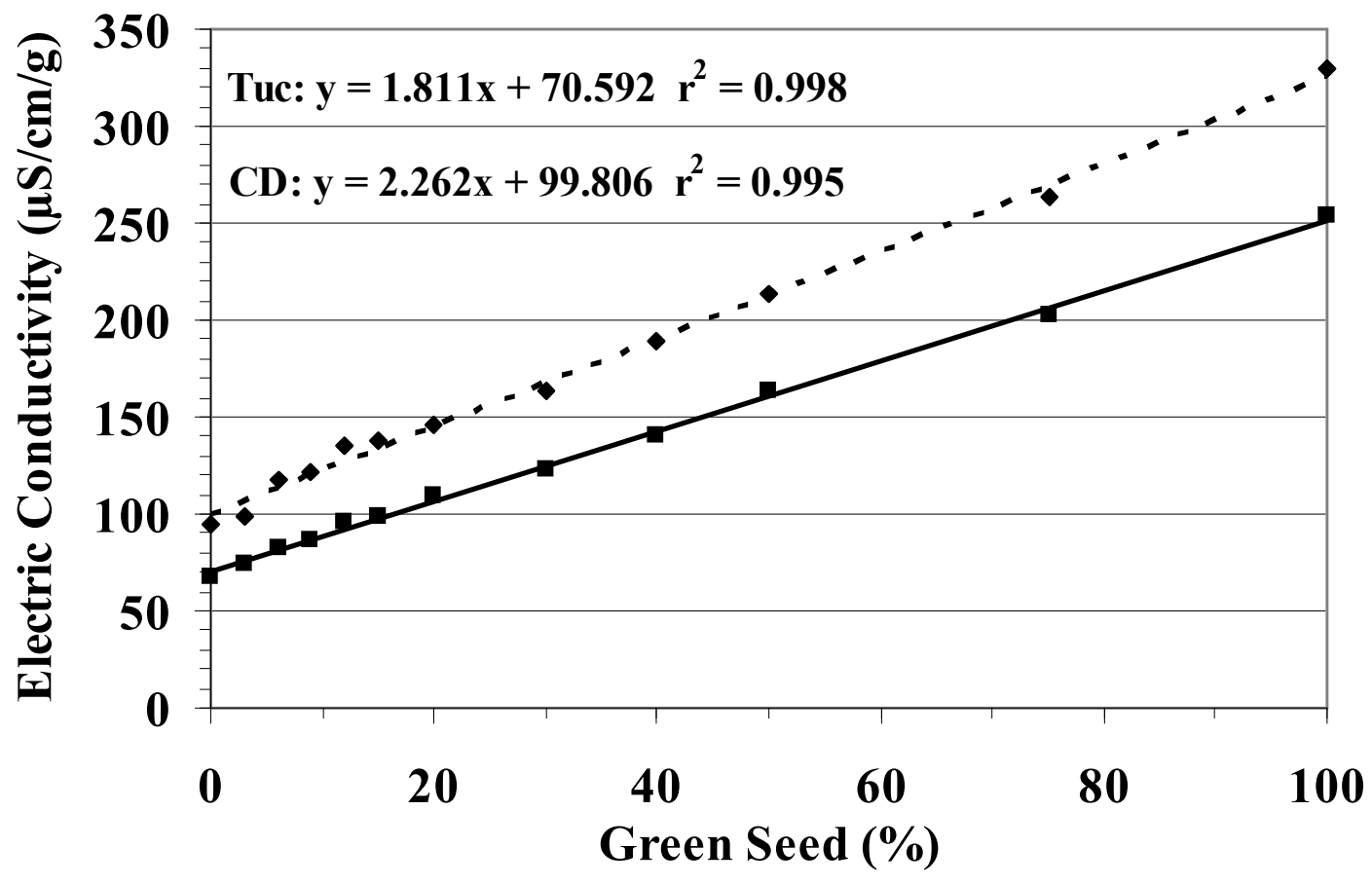

\section{Tucunaré $\cdots$. . CD 206}

FIGURE 4 - Electric conductivity in soybean seeds of the CD 206 (CD) and FMT Tucunaré (Tuc) cultivars in function of green seed percentage. UFLA, Lavras, MG, 2006.

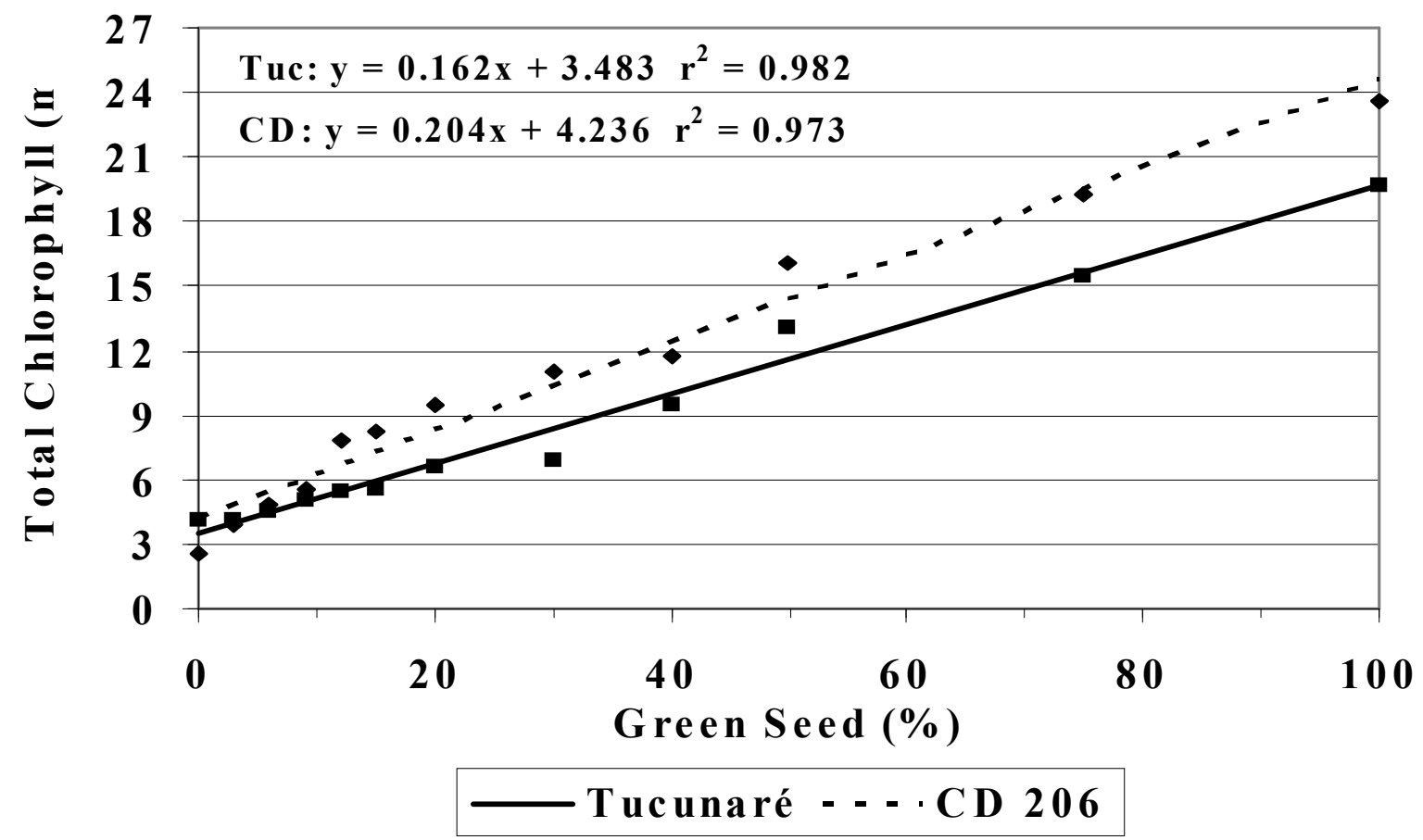

FIGURE 5 - $a$ chlorophyll (a), $b$ chlorophyll (b) and total chlorophyll (c) in soybean seed of the CD 206 (CD) and FMT Tucunaré (Tuc) cultivars, in function of the green seed percentage. UFLA, Lavras, MG, 2006. 
TABLE 3 - Effect of green seed levels on the $a, b$ and total chlorophyll contents in soybean seed of the CD 206 and FMT Tucunaré cultivars. UFLA, Lavras, MG, 2006.

\begin{tabular}{cccc}
\hline $\begin{array}{c}\text { Green } \\
\text { Seed } \\
(\%)\end{array}$ & \multicolumn{3}{c}{$\begin{array}{c}\text { Chlorophyll Content } \\
\left(\mathbf{m g . g}^{-1}\right)\end{array}$} \\
\cline { 2 - 4 } $\boldsymbol{a}$ & $\boldsymbol{b}$ & Total \\
\hline 0 & $2.317 \mathrm{a}$ & $1.408 \mathrm{a}$ & $3.727 \mathrm{a}$ \\
3 & $2.827 \mathrm{~b}$ & $1.627 \mathrm{a}$ & $4.453 \mathrm{~b}$ \\
6 & $3.188 \mathrm{~b}$ & $2.015 \mathrm{~b}$ & $5.202 \mathrm{~b}$ \\
9 & $3.692 \mathrm{c}$ & $2.198 \mathrm{~b}$ & $5.887 \mathrm{c}$ \\
12 & $4.511 \mathrm{c}$ & $2.870 \mathrm{c}$ & $7.376 \mathrm{c}$ \\
15 & $4.833 \mathrm{c}$ & $2.855 \mathrm{c}$ & $7.685 \mathrm{c}$ \\
20 & $5.498 \mathrm{c}$ & $3.448 \mathrm{c}$ & $8.946 \mathrm{c}$ \\
30 & $6.150 \mathrm{c}$ & $3.798 \mathrm{c}$ & $9.946 \mathrm{c}$ \\
40 & $7.058 \mathrm{~d}$ & $4.730 \mathrm{~d}$ & $11.785 \mathrm{~d}$ \\
50 & $9.852 \mathrm{~d}$ & $6.356 \mathrm{~d}$ & $16.200 \mathrm{~d}$ \\
75 & $11.082 \mathrm{~d}$ & $8.218 \mathrm{~d}$ & $19.295 \mathrm{~d}$ \\
100 & $14.823 \mathrm{~d}$ & $9.265 \mathrm{~d}$ & $24.080 \mathrm{~d}$ \\
\hline C.V. $(\%)$ & 17.69 & 15.30 & 16.89 \\
\hline
\end{tabular}

Means followed by the same lowercase letter in the column do not differ by the Scott-Knott tests at 5\% probability.

Thiagarajah (1990) detected a 2.5:1 ratio, and there may be a reduction in the $a: b$ chlorophyll ratio to $2: 1$, with the maturing of the rapeseed. The authors reported that $a$ chlorophyll is less stable than $b$ chlorophyll. Sinnecker (2002) worked with soybean seed and also verified that $a$ chlorophyll degraded faster than $b$ chlorophyll, with a reduction in content of $92 \%$ from the start of maturing $\left(\mathrm{R}_{6}\right)$ and complete maturing while for $b$ chlorophyll the reduction was $70 \%$ in the same period. In soybean seed in physiological maturity, this author observed a 1.8:1 ratio. The results obtained regarding the $a: b$ chlorophyll ratio in this research, in soybean seed harvested at harvest maturing, was $1.6: 1$, values close to those reported by Sinnecker (2002) in studies carried out during soybean seed maturing.

Figure 5 (c) shows the results of the total chlorophyll contents in the two cultivars assessed, for the different green seed percentages. The total chlorophyll contents expressed the results observed for the $a$ and $b$ chlorophylls. Similar to what occurred to the $a$ and $b$ chlorophylls, it was verified that chlorophyll levels in the two cultivars studied increased proportionally to the percentage of green seed.
It was generally emphasized in this research that the appearance of green seed in soybean seed lots results in sharp reduction in their qualities and as consequence a poor performance for commercial purposes.

\section{CONCLUSIONS}

The increase in green seed incidence in soybean seed lots negatively affects their quality and increases the chlorophyll contents in the seed.

Indices of up to $3 \%$ green seed in soybean seed lots did not cause reductions in germination, viability or vigor by the accelerated aging tests in the two cultivars under study.

Green seed levels greater than $9 \%$ reduces the quality of soybean seed lots for commercial purposes, because of their significant effects in reducing the physiological potential.

\section{REFFERENCES}

ARNON, D.I. Cooper enzymes in isolated chloroplasts. Polyphenoloxidases in Beta vulgaris. Plant Physiology, Minneapolis, v.24., n.1, p.1-15, Jan. 1949.

BOHNER, H. Green Soybeans. Disponível em: <http:// www.gov.on.ca/OMAFRA/english/crops/field/news/croptalk/ 2002/ct 1102a2. htm.> Acesso em: 12 jul. 2005.

BRASIL. Ministério da Agricultura e da Reforma Agrária. Regras para Análise de Sementes. Brasília: SNDA/DNDV/CLAV, 1992. 365p.

COSTA, N. P.; FRANÇA NETO, J.B.; PEREIRA, J.E.; MESQUITA, C.M.; KRZYZANOWSKI, F.C.; HENNING, A.A. Efeito de sementes verdes na qualidade fisiológica de sementes de soja. Revista Brasileira de Sementes, Brasília, v.23, n.2, p.102-107, 2001.

FERREIRA, D.F. Análises estatísticas por meio do Sisvar para Windows versão 4.0. In: REUNIÃO DA REGIÃO BRASILEIRA DA SOCIEDADE INTERNACIONAL DE BIOMETRIA, 45., São Carlos, 2000. Programas e resumos... São Carlos, SP: UFSCAR, 2000. p.255-258.

FRANÇA NETO, J.B.; KRZYZANOWSKI, F.C.; COSTA, N.P. O teste de tetrazólio em sementes de soja. Londrina: EMBRAPACNPSo, 1998. 72p. (Documentos, 116).

FRANÇANETO, J.B.;PÁDUA, G.P.; CARVALHO, M.L.M.; COSTA, O.; BRUMATTI, P.S.R.; KRZYZANOWSKI, F.C.; COSTA, N.P.; HENNING, A.A.; SANCHES, D.P. Semente esverdeada de soja e sua qualidade fisiológica. Londrina: Embrapa Soja, 2005. 8p. (Embrapa Soja. Circular Técnica 38). 
HEATON, J.W.; MARANGONI, A.G. Chlorophyll degradation in processed foods and senescent plant tissues. Trends in Food Science and Technology, Oxford, v.7, n.1, p.8-15, Jan. 1996.

JOHNSON-FLANAGAN, A.M.; THIAGARAJAH, M.R. Degreening in canola (Brassica napus, cv. Westar) embryos under optimum conditions. Journal of Plant Physiology, Jena, v.136, n.2, p.180-186, May 1990.

MARCOS FILHO, J. Teste de envelhecimento acelerado. In: KRZYZANOWSKI, F.C.; VIEIRA, R.D.; FRANÇA NETO, J.B. (Ed.). Vigor de sementes: conceitos e testes. Londrina: ABRATES, 1999. p.3.1-3.24.

MEDINA, P.F.; LAGO, A.A.; RAZERA, L.F.; MAEDA, J.A. Composição física e qualidade de lotes de sementes de soja com incidência de sementes esverdeadas. Informativo ABRATES, Curitiba, v.7, n.1/2, p.36, 1997.

McGREGOR, D.I. Influence of environment and genotype on rapeseed/canola seed chlorophyll content. Seed Science and Technology, Zurich, v.19, n.1, p.107-116, 1991.

MILLS, J.T.; WOODS, S.M.; WATTS, B.M.; LAMARI, L.; WHITE, N.D.G. Comparison of techniques to measure seed color and its relationship to other quality parameters in stored lentil (Lens culinaris Medik.). Seed Science and Technology, Zurich, v.27, p.1015-1021, 1999.

PAIVA AGUERO, J.A.P. Correlação de condutividade elétrica e outros testes de vigor com emergência de plântulas de soja em campo. 1995. 92p. Dissertação (Mestrado). Universidade Estadual de São Paulo, Jaboticabal.

PUPIM, T.L.; CARVALHO, M.L.M.; PÁDUA, G.P.; NERY, M.C.; FRANÇA NETO, J.B. Ocorrência de sementes verdes e qualidade fisiológica de sementes de soja. Informativo ABRATES, Londrina, v.15, n.1/2/3, p.238, 2005.
R. DEVELOPMENT CORE TEAM (2005). R: a language and environment for statistical computing. Viena: R Foundation for Statistical Computing. Disponível em: <http://www.R-project. org>. Acesso em: 2005.

SCHWARTZ, S.J.; LORENZO, T.V. Chlorophylls in foods. Critical Reviews in Food Science and Nutrition, Boca Raton, v.29, n.1, p.1-17, 1990.

SINNECKER, P. Degradação da clorofila durante a maturação e secagem de sementes de soja. 2002. 103p. Tese (Doutorado). Universidade de São Paulo, São Paulo.

TAKAMYIA, K.; TSUCHIYA, T.; OHTA, H. Degradation pathway(s) of chlorophyll: what has gene cloning revealed? Trends Plant Science, London, v.5, n.10, p.426-431, Oct. 2000.

VIEIRA, R.D. Teste de condutividade elétrica. In: VIEIRA, R.D.; CARVALHO, N.M. (Eds.) Testes de vigor em sementes. Jaboticabal: FUNEP, 1994. p.103-132.

VIEIRA, R.D.; KRZYZANOWSKI, F.C. Teste de condutividade elétrica. In: KRZYZANOWSKI, F.C.; VIEIRA, R.D.; FRANÇA NETO, J.B. (Ed.). Vigor de sementes: conceitos e testes. Londrina: ABRATES, 1999. p.4.1-4.26.

WARD, K.; SCARTH, R.; DAUN, J.; VESSEY, J.K. Chlorophyll degradation in summer rape and summer turnip rape during seed ripening. Canadian Journal of Plant Science, Ottawa, v.75, n.2, p.413-420, Apr. 1995.

ZORATO, M.F.; PESKE, S.T.; TAKEDA, C.; FRANÇA NETO, J.B. Sementes de soja que retém clorofila e qualidade fisiológica. Informativo ABRATES, Londrina, v.13, n.3, p.295, 2003. 